\title{
Cultic Allusions in the Heraklitos MosAIC
}

\author{
Alusiones Cúlticas en el mosaico \\ DE HerÁClito
}

\author{
EHUD FATHY
}

Tel Aviv University

Recibido: 05/02/2019 Evaluado: 16/03/2019 Aprobado: 01/05/2019

AbStRACT: The Heraklitos mosaic, which dates to the second century $\mathrm{AD}$ and is displayed today at the Vatican Museums, depicts the theme of the asàrotos oikos ('unswept floor') alongside allusions to Dionysian and Isiac mystery cults. The mosaic is well known due to its highly illusionistic depiction of scraps of food, which are scattered evenly across the room's floor, as if left behind -a theme which according to Pliny was first created by the mosaicist Sosus in Hellenistic Pergamon. The mosaic Pliny is referring to was never discovered, and the theme is known today only through five surviving Roman variations, the Heraklitos mosaic being the largest and most elaborate one. This article examines the ways in which the Heraklitos mosaic expresses the connection between power, social status and initiation into mystery cults in Imperial Rome, and explores the connection between traditional Roman beliefs, foreign cult practices and elitist artistic representation.

Keywords: Heraklitos; Sosus; asàrotos òikos; Dionysus; Isis; mystery cults; Nile; Roman elite.

ReSUMEN: El mosaico de Heráclito, procedente del siglo II d. C., que hoy en día se expone en los Museos Vaticanos, representa el tema del asàrotos òikos junto con alusiones a los cultos mistéricos dionisíacos e isíacos. El mosaico es bien conocido debido a su representación ilusionista de 
restos de comida que se encuentran dispersos en el suelo de la sala. Esta iconografía, según Plinio, fue creada por primera vez por el mosaiquista Sosus en el Pérgamo helenístico. El mosaico al que se refería Plinio nunca se encontró, y su tema se conoce solo a través de cinco variaciones romanas preservadas, de las cuales el mosaico de Heráclito es la más grande y detallada. Este artículo revisa las formas en las que este mosaico expresa la conexión entre el poder, el estatus social y el desarrollo del misticismo en la Roma imperial. Además, revela la conexión entre las tradicionales creencias romanas, las prácticas de culto extranjeras y la representación artística elitista.

Palabras clave: Heráclito; Sosus; asàrotos òikos; Dionisio; Isis; misticismo; Nilo; elite romana.

$\mathrm{T}$ he Heraklitos mosaic is known for its representation of the asàrotos oikos ('unswept floor') theme, in which scraps of food appear as if scattered across the room's floor in a highly illusionistic depiction. According to Pliny, this theme was created by Sosus in Pergamon. ${ }^{1}$ The mosaic Pliny is referring to was never discovered; however, the theme survived in five Roman variations. The Heraklitos mosaic is the largest and most elaborate representation of the asàrotos oikos theme, in which it appears alongside less clearly expressed references to the Dionysian and Isiac mystery cults. This article examines the ways in which the Heraklitos mosaic expresses the connection between the initiation into mystery cults and the elite's claim to exclusive power in Imperial Rome. It discusses the appearance of the asàrotos ìikos theme in relation to various religious traditions, explores the cultic allusions found in the other friezes, and suggests a thematic interconnection between the different subject matters.

The Heraklitos mosaic was discovered in Rome in 1833 (fig. 1). It dates to the beginning of the second century AD, and measures $4.10 \times 4.05 \mathrm{~m}$. It is signed in Greek: "Heraklitos has made me". ${ }^{2}$ The mosaic was discovered in a domus which was located in Vigna Lupi, south of the Aventine Hill and in front of the Aurelian Wall. It was part of a much larger room (nearly $11 \mathrm{~m}$ long), the rest of the floor was decorated using opus sectile and the walls were lined in marble. ${ }^{3}$

1. "This contribution is part of the author's doctoral thesis, carried out at Tel Aviv University, under the supervision of Dr. Talila Michaeli. PLIN. HN, 36.60.25

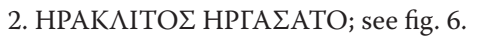

3. Karl Parlasca: "Das pergamenische Taubenmosaïk und der sogenannte Nestor-Becher", Jahrbuch des Deutschen Archäologischen Instituts, 78, 1963, p. 277; Michael Donderer: "Die antiken Pavimenttypen und ihre Benennungen”, Jahrbuch des deutschen archäologischen Instituts, 102, 1987, pp. 365-377; Klaus E. Werner: Die Sammlungen antiker Mosaiken in den Vatikanischen Museen, Monumenti, Musei e Gallerie Pontificie, Vatican City, 1998, pp. 260-262; Emil A. RiBI: "Asàrotos òikos - von der Kunst, die sich verbirgt”, in SAbrina Buzzi, DANiel KäCH, ERICH Kistler ET AL. (eds.): Zona Archeologica: Festschrift für Hans Peter Isler zum 60. Geburtstag, R. Habelt, Bonn, 2001, p. 364. 


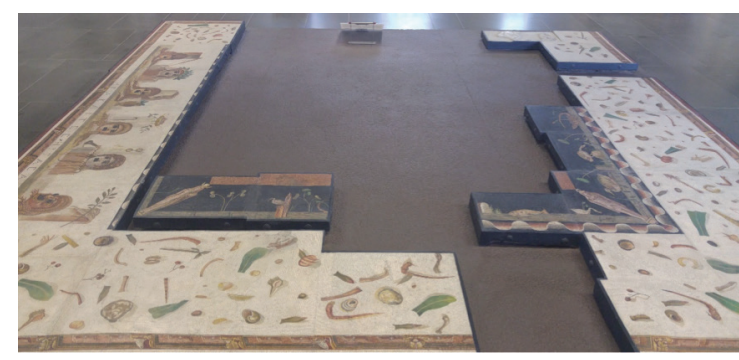

Fig.1. Heraklitos, asàrotos òikos, second century AD, discovered in a private house in Rome, in front of the Aurelian Walls and south of the Aventine Hill, now in Gregoriano Profano Museum, Vatican, dimensions: $4.10 \times 4.05 \mathrm{~m}$.

The asàrotos òikos theme appears in three other Roman mosaics. One was discovered in 1859 in Aquileia (fig. 2), it dates to the second half of the first century AD and measures $2.49 \times 2.33 \mathrm{~m}$. This mosaic too decorated the floor of a domus, the location of which was never precisely marked, but is known to have been situated northwest of the basilica and southeast of the forum. Upon discovery, the central emblema had already been extracted, leaving only two fragments: the wings of a bird in the upper right corner and the paw of a feline in the lower left corner. ${ }^{4}$

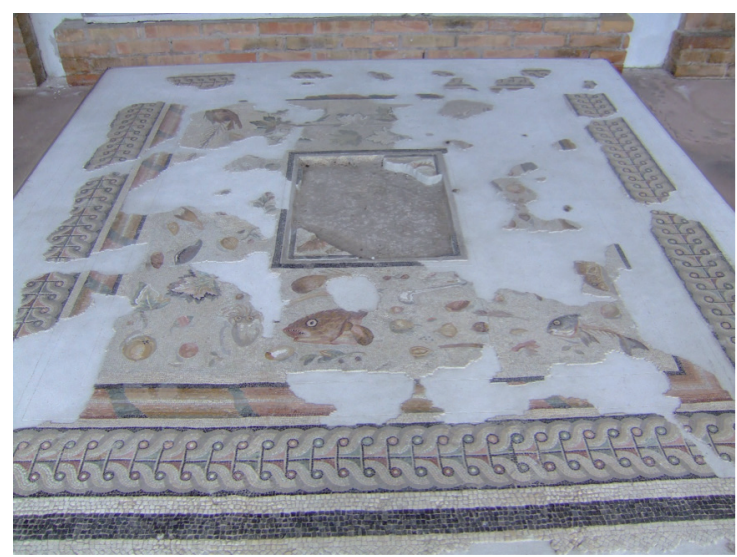

Fig. 2. Asàrotos oikos, second half of the first century to the beginning of the second century AD, discovered in a private house in Aquileia,

now in the National Archaeological Museum of Aquileia, dimensions: $2.33 \times 2.49 \mathrm{~m}$.

4. Paola Perpignani and Cesare Fiori: Il mosaico 'non spazzato.' Studio e restauro dellasaroton di Aquileia, Edizioni del Girasole, Ravenna, 2012, pp. 20-22, 24, 31-36. 
The other two mosaics were discovered in Tunis. The earlier one was discovered at Salonius House in Oudna (Uthina). The asàrotos òikos theme appeared as five separate emblemata, approx. $60 \times 70 \mathrm{~cm}$ each, which were part of a larger decorative scheme (fig. 3). While the domus itself dates to the third century $\mathrm{AD},{ }^{5}$ the asàrotos oikos emblemata were probably made during the end of the first or the beginning of the second century AD. ${ }^{6}$ The second Tunisian mosaic was discovered at the House of the Months in El Djem (Thysdrus). It dates to the beginning of the third century $\mathrm{AD}$. The decorative scheme is typical to triclinia: the U-shaped area is decorated with a geometric design, while the T-shaped area is decorated with xenia and Dionysian imagery. A narrow U-shaped frieze, in which scraps of food are depicted, connects these two parts (fig. 4).

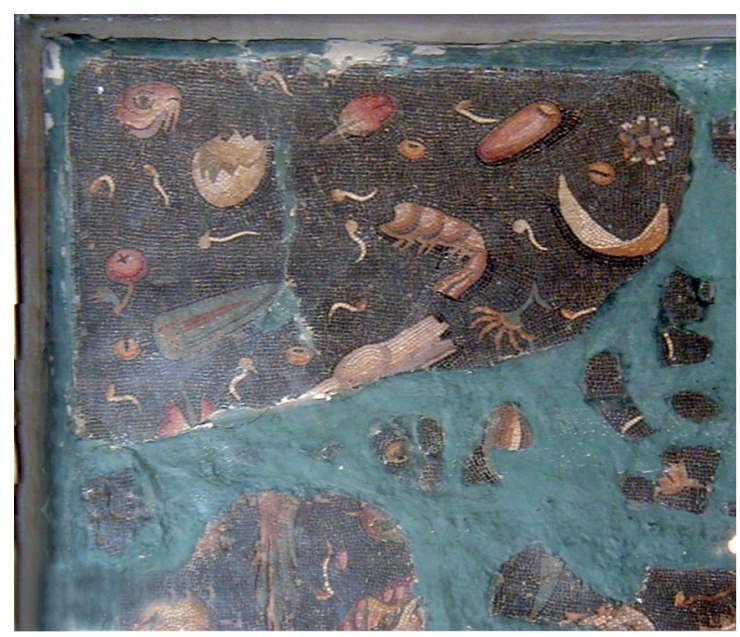

Fig. 3. Asàrotos òikos emblema, the end of the first or the beginning of the second century AD, discovered at Salonius House of the third century AD in Oudna (Uthina), now in the Bardo National Museum, Tunis, dimensions: $59.4 \times 71.4 \times 7.6 \mathrm{cms}$.

5. Based on coins of Maximian and Constantine which were found in the ground underneath, see: PAUL GaUCKLER: "Le domaine des Laberii à Uthina", Monuments et mémoires de la Fondation Eugène Piot, 3, 1896, p. 214; Waldemar Deonna and Marcel Renard: Croyances et superstitions de table dans la Rome antique, Collection Latomus, 46, Revue d'études latines, Bruxelles, 1961, p. 119.

6. GAUCKLER: "Le domaine des Laberii à Uthina", pp. 213-214; PAUl GAUCKLER: Inventaire des Mosaïques de la Gaule et de l'Afrique, volume II: Afrique Proconsulaire (Tunisie), Académie des inscriptions \& belles-lettres, Paris, 1910, p. 132 n. 388.3; Paul Gauckler: "Musivum opus", in Charles Victor Daremberg, Edmond Saglio and Edmond Pottier (eds.): Dictionnaire des antiquités grecques et romaines d'après les textes et les monuments, III/2, 1904, Librarie Hachette, Paris, p. 2099 n. 5; Louis Foucher: "Une mosaïque de triclinium trouvée à Thysdrus", Latomus, 20, 1961, p. 297 n. 4 pl. xviII; DeOnNa: Croyances et superstitions de table dans la Rome antique, p. 119; PARLASCA: "Das pergamenische Taubenmosaïk und der sogenannte Nestor-Becher", p. 280; Jan Willem Salomonson: Romeinse Mozaïeken uit Tunesië, Rijksmuseum van Oudheden, Leiden, 1964, pp. 46-47; KATHERINE M.D. Dunbabin: The Mosaics of Roman North Africa: Studies in Iconography and Patronage, The Clarendon Press, Oxford, 1978, p. 17 n. 19; MrChele Blanchard-Lemée, Mongi Ennaïfer, Hedi Slim and Latifa Slim: Mosaics of Roman Africa: Floor Mosaics from Tunisia, G. Braziller, New York, NY, 1996, p. 78. 


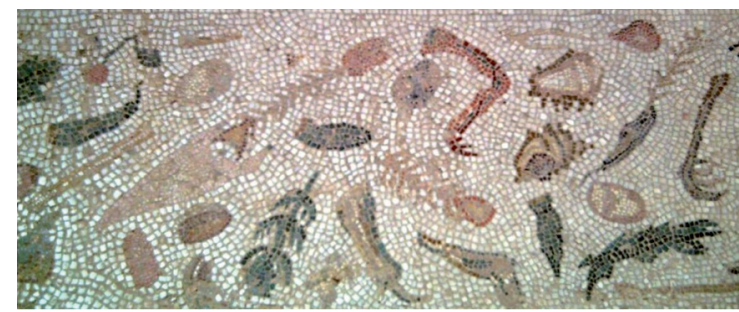

Fig. 4. Asàrotos oikos (detail), 210-235 AD, discovered at the House of the Months in El Djem (Thysdrus), now in Sousse Archaeological Museum, Tunis.

The appearance of the asàrotos òikos theme in the Heraklitos mosaic could be put into context by the atmosphere of the period, also known as the "Second Sophistic", which was characterized by a conscious effort to revive the glorious cultural past of Hellenic times. ${ }^{7}$ In the spirit of the time, the Heraklitos mosaic was designed to appeal to an erudite individual, who cultivated a sophisticated taste, and who could appreciate the ironic qualities of the theme and the many references embedded in the mosaic. At that time, the Roman elite used art as a social signifier. The intellectual discourse regarding artworks and their merits was founded on elements taken from the rhetorical practices, which were a key component in the pedagogy of elitist education. ${ }^{8}$ It was a reaction to the increasing social mobility, which had blurred the boundaries between the different classes. The Roman higher class wished to maintain a feeling of cultural superiority over the freedmen, who were now rapidly increasing in wealth and in political power. In order to reconstruct some form of social hierarchy, a sophisticated artistic culture had been cultivated. ${ }^{9}$ Made to fit into this elitist mode of viewing art, the artworks themselves were sometimes designed in order to stimulate a rhetorical discourse. Consideration was not only given to each individual image, but also to the relationships between the different subject matters, and to the collective theme which arose from their collocation. ${ }^{10}$

The Heraklitos mosaic is a good example of such an elitist artwork. ${ }^{11}$ It depicts several seemingly unrelated subject matters: three friezes depict scraps of food and a mouse sniffing a walnut (fig. 5); one frieze depicts theatre masks and items associated with the Dionysian mystery (fig. 6); two inner friezes depict Isis, Osiris, the flooding of the Nile and the river's flora and fauna (figs. 7, 8); while the margins depict the mirrored image of the roof (figs. 5, 9).

7. Graham Anderson: The Second Sophistic: A Cultural Phenomenon in the Roman Empire, Routledge, London and New York, NY, 1993, pp. 1-2

8. Jeremy Tanner: The Invention of Art History in Ancient Greece: Religion, Society and Artistic Rationalisation, Cambridge University Press, Cambridge, 2006, p. 246

9. Gell. NA, 13, 17.1, see also: TANner: The Invention of Art History in Ancient Greece, pp. 274-275.

10. Richard Brilliant: Visual Narratives: Storytelling in Etruscan and Roman Art, Cornell University Press, Ithaca, NY and London, 1984, pp. 69-73.

11. Ehud Fathy: "The asàrotos òikos Mosaics as an Elite Status Symbol", Potestas, 10, 2017, pp. 10-17. 


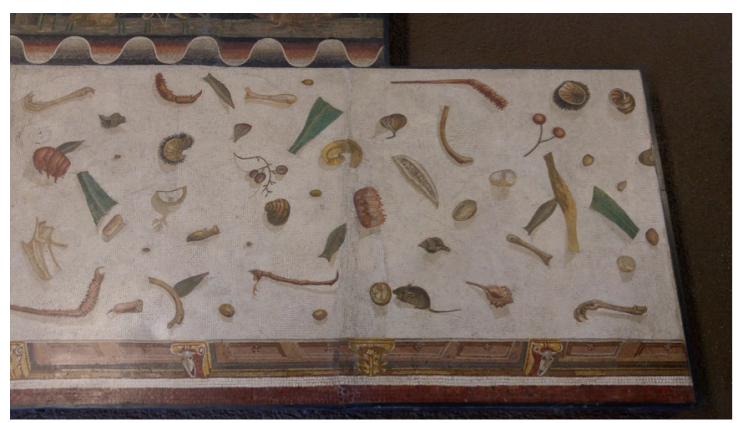

Fig. 5. Scraps of food, torn leaves and broken branches, a mouse sniffing a walnut, and the mirrored image of the roof (with illusionary cassettoni, rosettes and interchanging bucrania and acanthus leaves), detail from fig. 1.

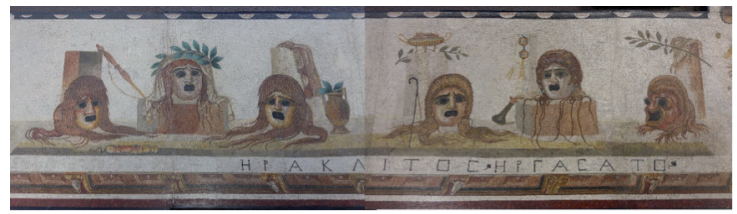

Fig. 6. Theatre masks and instruments associated with the Dionysian mystery, below them the signature "НРАК $\Lambda$ ITO $\Sigma$ НРГА $\Sigma$ ATO", detail from fig. 1.

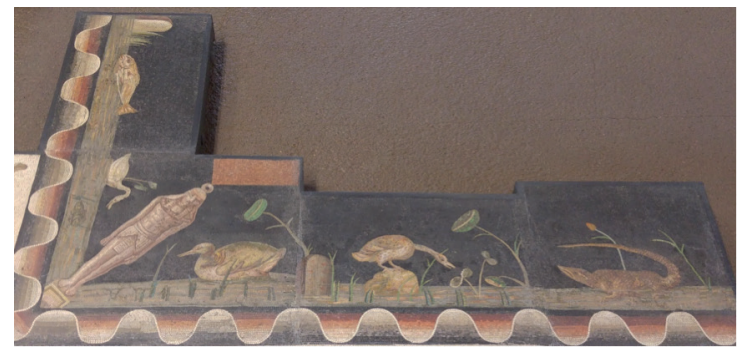

Fig. 7. Osiris, the flooding of the Nile, three geese, a crocodile, a frog, a fish, reeds and pink lotuses, detail from fig. 1.

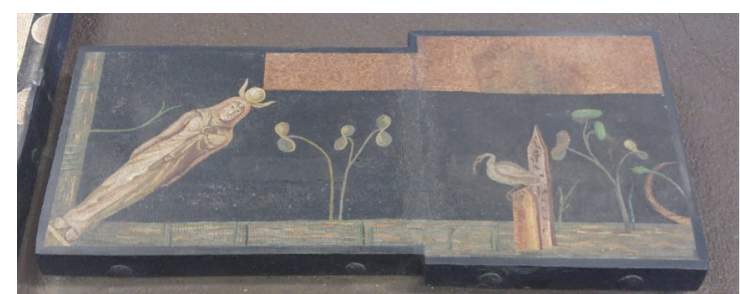

Fig. 8. Isis, the flooding of the Nile, an ibis, the tail of a crocodile, a nilometer (?) and the river's flora, detail from fig. 1. 


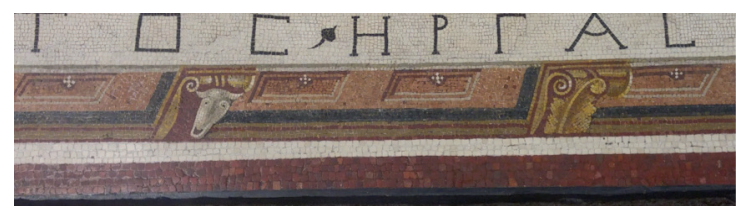

Fig. 9. The mirrored image of the roof, with bucrania, acanthus leaves, cassettoni and rosettes, detail from fig. 1.

Several discourses could have been prompted by the asàrotos òikos friezes, such as the luxurious dining practices of the ancient Greeks, the mosaics Sosus created in Pergamon as described by Pliny, Zeuxis and Parrhasius' painting competition or other literary accounts which discuss the tension between reality and artistic depiction. ${ }^{12}$ The discourse could have also touched on the tension between the mosaics representation of mores maiorum ("'ways of the forefathers"') versus foreign luxuria and mystery cults. ${ }^{13}$

In both of the Italian mosaics, the friezes which depict scraps of food are the most dominant ones and circle the perimeter of the room. They seem to be representing the aftermath of a luxurious banquet, and, therefore, could be part of the visual representation of the carpe diem theme. ${ }^{14}$ This theme was associated with banqueting in Roman literature and poetry, as well as in the rituals of the banquet itself. It urged the banquet's participants to enjoy the food, wine, luxury and general hedonistic atmosphere of the event while they lasted. ${ }^{15}$ However, the depiction of scraps of food could have also represented an offering to the deceased, a custom that is mentioned in ancient literature. ${ }^{16}$ Trimalchio addresses the custom of pouring wine on graves in mourning: when his servants spill expensive wine (Falernum) on the floor, Trimalchio proclaims that they are pouring the wine in his memory (as a funerary libation). ${ }^{17}$ Lucian, on the other hand, mocks the custom of pouring wine on the graves, asking in the voice of a deceased young man whether the pourer expects the wine to drip all the way to Hades. ${ }^{18}$ According to Diogenes Laërtius it was prohibited to taste the food which fell underneath the table. He cites two explanations for

12. Pl. Resp., 10.601a-603b; Vitr. De arch., 7.5.3-4; Plin. HN, 35.65-6, 95; Strabo, 14.2.5; Ael. VH, 2.3; see also: John R. Clarke: The Houses of Roman Italy: 100 B.C.-250 A.D.: Ritual, Space, and Decoration, University of California Press, Berkeley, CA and Oxford, 1991, pp. 49-50

13. FAтнy: "The asàrotos òikos Mosaics as an Elite Status Symbol", pp. 25-26.

14. Ibid., pp. 18-22.

15. Petron. Sat., 34; see also: Katherine M.D. Dunbabin: "'Sic erimus cuncti...' The Skeleton in Greco-Roman Art", Jahrbuch des Kaiserlich Deutschen Archäologischen Instituts, 101 (1986), pp. 196-203, 212 213, 224-228; Peter Stewart: The Social History of Roman Art, Cambridge University Press, Cambridge, mA and New York, NY, 2008, pp. 60-61; PAul ZAnker: Roman Art, J. Paul Getty Museum, Los Angeles, CA, 2010, pp. 27-32.

16. Ov. Fast. 2.533-570.

17. Petron. Sat. 28.

18. LuC. Luct. 19 
this prohibition. The first is based on quote by Aristotle regarding the mystical-religious prohibitions of Pythagoras, who preached for the need of moderation and restraint in food consumption, and therefore forbade his disciples to eat the food which fell underneath the table. ${ }^{19}$ The second explanation is related to "a man's death", in this context, Diogenes quotes a line from a lost Aristophanes play, which mentions the prohibition to taste the food which fell underneath the table, since these crumbs belong to the "heroes" ${ }^{20}$ The same tradition is also mentioned by Athenaeus. ${ }^{21}$

George Elderkin suggests that the asàrotos oikos theme was related to household cult. The deceased were worshipped as heroes and sometimes buried in their houses. Therefore, the scraps of food that fell underneath the table could be regarded as theirs. ${ }^{22}$ Servius explains that this kind of burial is the reason why the Lares were worshipped in private houses. ${ }^{23}$ According to Elderkin, the patron who wished to appease his Lares, but for sanitary reasons did not wish for his dining room floor to be littered, found a compromise in the form of depicting scraps of food in a mosaic pavement. This idea was borrowed from the painting or carving of garlands upon altars as a permanent substitute for the real ones. ${ }^{24}$

Pliny notes that, in the olden days, if a visitor dropped food on the floor, it was considered an ominous sign, and that it was forbidden to blow on the food in order to clean it. It was a particularly ominous sign if this happened to the pontiff during the festival dedicated to Dis Pater. ${ }^{25}$ The proper atonement in such cases was to return the crumb that fell to the table, and then to burn it as an offering to the Lares. ${ }^{26}$ This tradition is also mentioned by Servius. ${ }^{27}$ According to Pliny, if the floor was swept while the diners rose from the table, or if a table or a food stand were removed while a guest was still drinking, it was considered a sign of great misfortune. He explains that these customs were created by the forefathers, who believed that the gods were omnipresent, and therefore looked for means of appeasing them, even in $\sin .{ }^{28}$ In Satyricon appears a prohibition to touch utensils which fell on the floor during the banquet. ${ }^{29}$ Indeed, the Aquileia mosaic depicts a ladle (simpulum) which fell on

19. Arist. On the Pythagoreans cf. Diog. LAert. 8.1.(34).

20. Ar. Íroes (í $\rho \omega \varepsilon \varsigma)$ cf. August MeIneke: Fragmenta Comicorum Graecorum, typis et impensis G. Reimeri, 1839, Vol. I, p. 285, frag. $(2,1070)$.

21. Атн. $10.427 \mathrm{e}$.

22. George Wicker Elderkin: "Sosus and Aristophanes", Classical Philology, 32/1, 1937, p. 75.

23. "Apud maiores omnes in suis domibus sepeliebantur unde ortum est ut Lares colerentur in domibus": SERV. In Vergilii carmina commentarii, 6.152.

24. EldERKIN: “Sosus and Aristophanes", p. 75.

25. This probably refers to the Parentalia festival, which lasted nine days (dies parentales), and was held each year between February 13th and 21st.

26. Plin. HN, 28.5.(27.)

27. SERV. In Vergilii carmina commentarii, 6.152.

28. Plin. HN, 28.5.(26-27.)

29. Petron. Sat. 34 
the floor (fig. 2). These prohibitions to sweep the floor or to move the furniture before the end of the meal give rise to the question of when and how were the guests to see the mosaic. If the floor had already been covered in sawdust for its protection before the banquet began, and cleared only after the guests left or moved to a different room, then the mosaic was completely hidden throughout the meal. ${ }^{30}$ This reinforces Elderkin's claim that the importance of the representation lies in the constant protection it provides. Even if the scraps of food were not visible during the banquet itself, they were always there, on the floor below the revellers' feet.

However, the quote from Aristophanes could also be interpreted differently: when the word "hero" appears in the context of the Dionysian mystery rites, it could refer to the god himself or to the priest conducting the ritual. A Greek inscription on the marble base of a Roman statue from the second century AD, dedicated to Pompeia Agrippinilla (a fairly well-known Roman family with Greek roots), documents the various positions within the cult, alongside the cognomina of the individuals who held them. ${ }^{31}$ At the top of the list is the title heros ("hero"), which refers to the leader of the cult. According to John Scheid, the title refers to a deceased individual who was associated with the cult and who was worshipped. ${ }^{32}$ Franz Cumont attributes the title to Dionysus himself, and adds that the leaders of the cult were sometimes named after the god which they served. ${ }^{33}$ Perhaps they were even dressed as Dionysus. ${ }^{34}$

According to Richard Gordon, one of the devices of the non-traditional religions of the Graeco-Roman world was secrecy. Reticence was not merely a means of self-protection, but an essential part of their appeal: the secrecy of the non-traditional religions contrasted with the public character of the dominant civic cults, and was intimately associated with the cultural and political power of the elite. While oral myths were perceived as the common property of the people, interpretative writings were regarded as the sole property of the wise. The approach to the mystical truth was perceived as valuable because of its rarity. Meanings devised by individual ingenuity could easily be imposed upon a self-elected community, while the commentary and the

30. Petron. Sat. 68; Hor. Sat. 2.4.70-95; see also: François Mazois: Le Palais de Scaurus, ou Description d'une maison romaine, fragment d'un voyage fait à Rome, vers la fin de la République, par Mérovir, prince des Suèves, Firmin Didot, Paris, 1819 (1859), p. 256; John F. Donahue: The Roman Community at the Table During the Principate, University of Michigan Press, Ann Arbor, MI, 2004, p. 132.

31. Elizabeth de Grummond: "Bacchic Imagery and Cult Practice in Roman Italy", in Elaine K. Gazda (ed.): The Villa of the Mysteries in Pompeii: Ancient Ritual, Modern Muse, Kelsey Museum of Archaeology and the University of Michigan Museum of Art, Ann Arbor, MI, 2000, pp. 75-78.

32. John SCHEID: "Le thiase du Metropolitan Museum", in L'association dionysiaque dans les sociétés anciennes, Actes de la table ronde organisée par l'École Française de Rome (Rome 24-25 mai 1984), Rome, 1986, pp. 275-290.

33. Franz V.M. Cumont: "La grande inscription bacchique du Metropolitan Museum iI: Commentaire religieux de l'inscription”, American Journal of Archaeology, 37, 1933, pp. 238-239.

34. Michael Koortbojian: Myth, Meaning, and Memory on Roman Sarcophagi, University of California Press, Berkeley, CA, 1995, p. 8, fig. 3. 
writings that enshrined it could become guardians of exclusivity. ${ }^{35}$ According to Origen, while Egyptian scholars who have studied the traditional writings provide profound philosophical interpretations of what they regard as divine, common people hear certain myths of which they are proud, although they do not understand their meaning. ${ }^{36}$ To be initiated into a mystery cult was to make a claim to power. This power was granted by the acquisition of secretive knowledge, which was guarded in the cults. It was ideally an ancient knowledge, which was revealed by certain "wise nations." ${ }^{37}$ The very existence of this depended upon the norm of public knowledge and acknowledgment that grounded the civic religions of antiquity. ${ }^{38}$

Some of the scattered foodstuffs in both of the Italian mosaics carry "disguised symbolism" which refers to Dionysus. ${ }^{39}$ For example, grapes, which, as Philostratus attests, evoke thoughts of the "god of wine". ${ }^{40}$ Also depicted are pine cones, which are associated in ancient literature with the Dionysian celebration. ${ }^{41}$ The appearance of figs and apples may hint at their myths of discovery by Dionysus. ${ }^{42}$ Several pomegranate seeds are depicted in the Heraklitos mosaic. According to Clemens, during the Thesmophoria, women refrained from eating pomegranate seeds which fell on the floor because of their belief that this fruit originated from the blood droplets of Dionysus, while a mystical ritual in honour of Dionysus included a snake, pomegranates and ivy leaves. ${ }^{43}$

The margins of the Heraklitos mosaic depict a mirrored image of the roof, decorated with bucrania and acanthus leaves (fig. 9). According to Plutarch, a specific connection exists between Dionysus and the bullheads, for the Greeks would erect statues of Dionysus in the form of a bull and one of the epithets of the god in Argos was "son of the bull".44 Being an herbaceous plant, the acanthus is an ideal symbol of regeneration and cyclical regrowth..$^{45}$ The appearance of

35. Richard Gordon: "Authority, Salvation and Mystery in the Mysteries of the Mithras", in JANet Huskinson, Mary Beard and Joyce Reynolds (eds.): Image and Mystery in the Roman World, Alan Sutton Publishing, Gloucester, 1988, p. 45.

36. Origen, C. Cels. 1.12 .

37. Philo, Quod omnis probus liber, 74-75, 92-96; Origen, C. Cels. 1.14, 16; Diog. Laert. 1.1-11; August. De civ. D. 8, 9.

38. Gordon: "Authority, Salvation and Mystery in the Mysteries of the Mithras", p. 45.

39. "Disguised symbolism" is an idea which was introduced by Erwin Panofsky in order to explain how apparently realistic representations of everyday objects and motifs could carry extensive symbolic significance. Panofsky noted that a correlation existed between an increased interest in naturalism and the use of disguised symbolism: "The more the painters rejoiced in the discovery and reproduction of the visible world, the more intensely did they feel the need to saturate all its elements with meaning".

ERwin PAnOfsky: Early Netherlandish Paintings, Its Origins and Character, Harper \& Rowe, New York, NY, 1971, pp. 140-142.

40. Philostr. Imag. $1.31 ; 2.17 .8$.

41. Strabo 10.3.13; Diod. Sic. 4.4.4; Ath. 1.33; Paus. 1.2.7; Eur. Bacch.106-110, 702-704.

42. Атн. 3.78a, 3.82d.

43. Clem. Al. Protr. 2.176-177.

44. Plut. Mor. De Is. et Os. $364 \mathrm{f}$.

45. Vitr. De arch., 4.1.9. 
bucrania and acanthus leaves in close proximity to various fruits that ripen at different times of the year could refer to the agricultural worship of Dionysus as a god associated with the promise of abundance and with the annual cycle of the seasons. ${ }^{46}$

The Aquileia mosaic prominently depicts a vine branch, while vine and ivy leaves are scattered among the foodstuffs. Ivy appears in ancient literature in the context of the cult of Dionysus. ${ }^{47}$ Pliny writes that consuming ivy berries in large quantities interferes with the mental activity and purifies the mind, and adds that pressing young ivy leaves around the head is beneficial for the relief of headaches. ${ }^{48}$ Therefore, the wearing of ivy wreathes around the head could also be associated with the banquet, in the desire to relief headaches which occur after consuming large quantities of wine.

The Heraklitos mosaic includes a large frieze, which depicts six theatre masks together with objects that refer to Dionysus: panther skin, laurel branches, a kantharos containing red grapes, a glitsa (an attribute of Pan) and a reddishpurple robe (fig. 6). According to the direction of Heraklitos' signature, this frieze probably stood at the entrance to the room, and therefore was the most visible one. The appearance of theatrical masks next to instruments associated with the Dionysian mystery is known from other Roman artworks. Frescoes in the House of the Vettii depict the theatre masks of Papposilenus and of a young man wearing an ivy wreath leaning against a liknon. ${ }^{49} \mathrm{~A}$ Papposilenus mask is depicted as part of the initiation into the Dionysian cult in the Villa of the Mysteries (fig. 10). A second century AD mosaic, which was discovered on the Aventine Hill, depicts two comic masks (virgo and servus) together with an ivy wreath and a double flute (fig. 11). A mosaic from Hadrian's Villa (displayed today at the Gabinetto Delle Maschere in the Vatican Museums) depicts a theatre mask together with vine and ivy wreaths, a reddish-purple robe, a small vine, a tambourine, a panther, a kantharos, an olive tree and a laurel tree. Miniature pan heads that sniff purple bindweed flowers appear in the margins. This too could refer to Dionysus, as Euripides mentions bindweed flowers in the context of the Bacchanalia. ${ }^{50}$

46. Almonds bloom in early spring, but their fruit ripens only six months later, in early autumn. Pomegranate and grapes ripen in early autumn too, whereas nuts ripen at the end of autumn. Cherries and strawberries ripen in late spring. The apple ripens at the beginning of summer, and the main ripening period of the figs is at the height of summer. The ripening of dates begins at the end of the summer and ends at the end of autumn. Hence, the mosaic depicts in close proximity scraps of fruit which ripen at different times of the year, and therefore it represents the abundance of agricultural produce throughout the seasons.

On the connection between bucrania and the agricultural worship of Dionysus see: PHYLLIS WILLIAMS Lehmann: Roman Wall Painting from Boscoreale in the Metropolitan Museum of Art, Archaeological Institute of America, Cambridge, MA, 1953, pp. 16-7, 81.

47. Eur. Bacch. 70 ff; Strabo 10.3.13; Paus. 10. 29. 4; Philostr. Imag. 1.15; Plin. hN, 16.62.(34.).

48. Plin. HN, 24.47.

49. For images see: http://cort.as/-KFht

50. Eur. Bacch. $70 \mathrm{ff}$. 


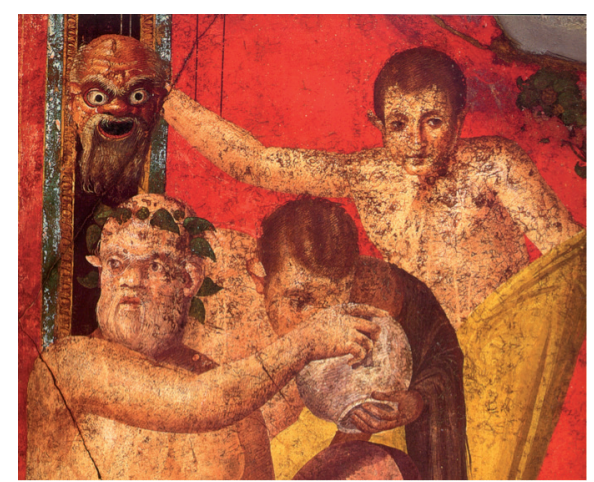

Fig. 10. Papposilenus with an ivy wreath holding a cup, two youths depicted as Pans with little goat ears, one is holding a Papposilenus mask, fresco, 60-40 вС,

Sala di Grande Dipinto, east wall, scene vi, Villa of Mysteries, Pompeii.

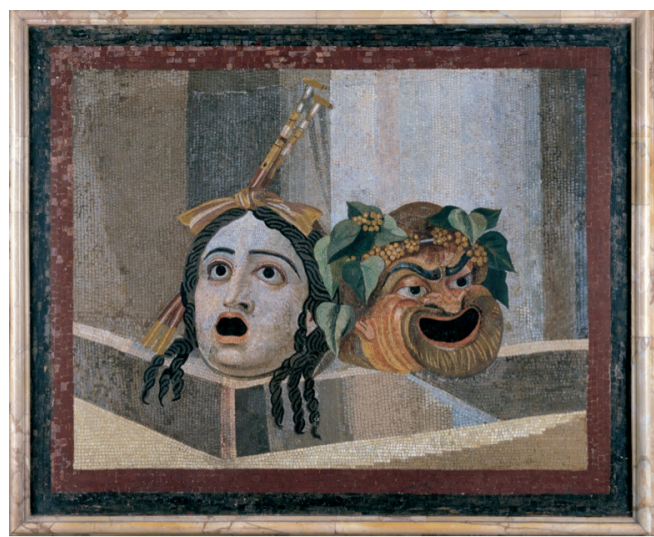

Fig. 11. Two comic masks (virgo and servus) together with an ivy wreath and a double flute, mosaic, second century AD, discovered on the Aventine Hill, today in Musei Capitolini, Rome, inv. MC0392.

The panther is often associated with Dionysus as a god who controls the wild forces of nature. ${ }^{51}$ Many times, Dionysus is depicted riding a panther or with a panther at his feet. The panther skin which appears in the Heraklitos mosaic may have been worn by the Dionysian cult leader during the ceremony. ${ }^{52}$ According to Diodorus, during times of war, Dionysus arrayed himself in arms and panther skins, but in assemblages and at festive gatherings in times

51. Margherita Carucci: The Romano-African Domus: Studies in Space, Decoration and Function, Archaeopress, Oxford, 2007, p. 55.

52. Cumont: "La grande inscription bacchique", pp. 238-239; Koortbojian: Myth, Meaning, and Memory on Roman Sarcophagi, p. 8, fig. 3; DE GRUMmOND: "Bacchic Imagery and Cult Practice in Roman Italy", p. 80. 
of peace, he wore brightly coloured garments, luxurious in their effeminacy. ${ }^{53}$ Athenaeus describes a huge procession in honour of Dionysus, which took place in Alexandria under the reign of Ptolemy in Philadelphus, and in which two tall statues of the god were clad in purple garments and the revellers wore purple, scarlet and vermilion. ${ }^{54}$ The purpura (Tyrian purple/red) dye was produced from predatory sea snails named Bolinus brandaris. The dye was highly prized in ancient times; it was prohibitively expensive and was only used by the highest ranking aristocracy. Alexander the Great, who during the conquest of the Persian Empire abandoned the simpler Macedonian dress and adopted the Persian signs of authority, brought it to the Hellenistic world. ${ }^{55}$ During the reign of Augustus, the purpura was associated with monarchy, mythological heroes, divine figures and general abundance. ${ }^{56}$ The love of purpura reached its peak during the second century $\mathrm{AD}$, and moral criticism began to emerge against this show of ostentatiousness. Apollonius scolded men for dressing in purpura at the Dionysian festival, a colour that he regarded as effeminate because of its association in the Euripidean drama with the female followers of Dionysus. ${ }^{57}$ In the Heraklitos mosaic, a reddish-purple robe appears behind the third mask to the left, and Bolinus brandaris shells are scattered among the food scraps. These references to purpura are not only meant as an elitist status symbol, an indication of imperial authority, an allusion to abundance or an expression of wealth, but also, more specifically, relate to the Dionysian mystery cult.

Behind the mask to the furthest left, a distaff leans against the wall and in front of it a spindle with a bit of loose thread rests on the floor (fig. 6). These could be associated with Klotho, or her Roman equivalent Nona, the youngest of the three Moirai or Parcae. The meaning of Klotho's name in Greek is "the weaver", since she is the one who weaves (or unravels) the thread of life, she decides when people will be born and die, and she determines their fate at birth. Lucian describes Klotho's roles in several of his writings alongside metaphors relating to spinning a thread. ${ }^{58}$

According to Diodorus, in order to avoid post-drinking headaches, Dionysus used to tie a mitra around his head, which is the reason for his epithet

53. Diod. Sic. 4.4.4.

54. Some revellers were dressed up as Sileni, clad in purple and scarlet cloaks, or as Satyrs in purple and vermilion body paint; boys were dressed in purple tunics; a statue of Dionysus pouring wine was clad in a purple tunic and another purple garment embroidered with gold; a second statue of Dionysus riding an elephant was clad in a purple robe; maidens dressed in purple tunics; and soldiers wore purple cloaks: Атн.5.197c-198d. p. 29.

55. Meyer Reinhold: History of Purple as a Status Symbol in Antiquity, Latomus, Bruxelles, 1970,

56. Verg. Aen. 4.462; Hor. Carm. 2.16.36; Tib. Tibvlli aliorvmque carminvm libri tres, 2.4.28; SulPicia, Elegiarum, 11.13 .

57. Philostr. VA, 4.21; Eur. Bacch. 980.

58. LuC. Dial. mort.; Iupp. trag; Catapl. 
"Miterphorus". ${ }^{99}$ Some statues of Dionysus depict a golden redimiculum/mitra tied around the god's head. ${ }^{60}$ In the Heraklitos mosaic, the second mask to the right is wearing a crossover ribbon decorated with golden squares (fig. 12). Crossover ribbons were associated in ancient Greece with the "other", the inhuman or the underworld. Hades, Erotes and Dionysus are sometimes depicted wearing crossover ribbons, as well as the disciples of various mystery cults, including that of Dionysus. ${ }^{61}$ The crossover headband which appears in the Heraklitos mosaic creates a link between these two traditions: the attempt to avoid a hangover, and an item associated with the initiation into the Dionysian mystery cult.

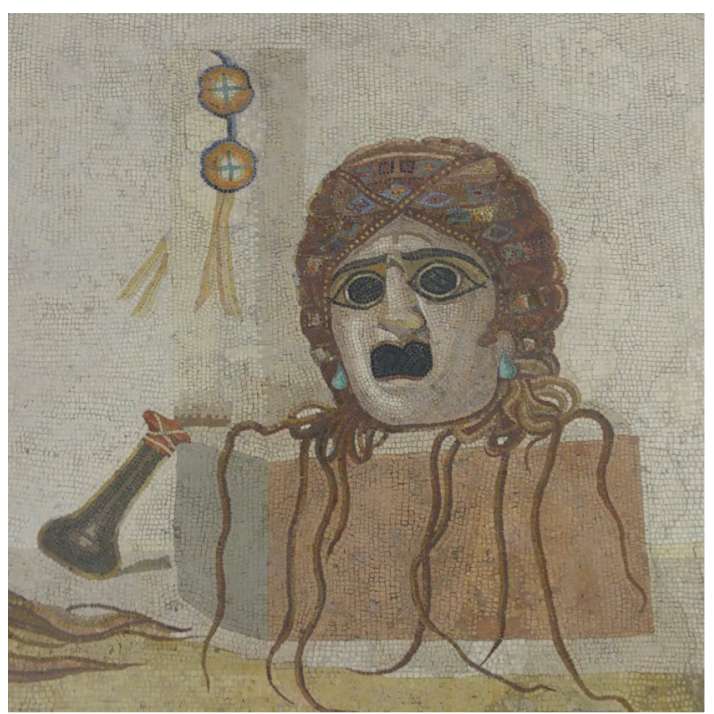

Fig. 12. A theatre mask wearing a crossover ribbon decorated with golden squares, a green cosmetics bottle and a rosette headband, detail from fig. 1 .

The Dionysian cult of Roman times was substantially different from that of the Greek, insofar as it was largely based on Euripides' Bacchae. The play had great influence on Romans who wanted to imitate the Dionysian rites, and they adopted it as a role model. In that sense, the Dionysian mystery ritu-

59. Diod. Sic. 4.4.4.

60. Molly Swetnam-Burland: "Bacchus/Liber in Pompeii: A Religious Context for the Villa of the Mysteries Frieze", in Elaine K. Gazda (ed.): The Villa of the Mysteries in Pompeii: Ancient Ritual, Modern Muse, Kelsey Museum of Archaeology and the University of Michigan Museum of Art, Ann Arbor, MI, 2000, pp. 67-68.

61. Rossitsa Gicheva-Meimari: "Crossbands on the Chest: Religious Realia in Ancient and Byzantine Thrace", in Charalambos Bakirtzis, Nikos Zekos and Xenophon Moniaros (eds.): Byzantine Thrace: Evidence and Remains, Verlag Adolf M. Hakkert, Amsterdam, 2011, pp. 359-362. 
als that took place in Rome were conceived as a theatrical performance, in which the disciples dressed and acted as characters in the Euripidean drama. ${ }^{62}$ Dionysian themes were commonly used in the decoration of triclinia and other rooms that were used for ritualistic feasts or other worship rites of the god. ${ }^{63}$ If the Heraklitos mosaic decorated a triclinium floor, then the theatre masks, the panther skin and the reddish-purple robe could be an artistic representation of the actual accessories that were used in a theatrical performance of the Dionysian mystery rites, which took place in the domestic sphere.

Only one more asàrotos òikos mosaic includes such a direct reference to the Dionysian mystery. It is the triclinium mosaic, which was discovered at the House of the Months in El Djem. The T-shaped area depicts agricultural produce together with theatrical masks: a maenad mask with flowers and a tambourine, a pan mask with a double flute, a Dionysian mask and a satyr mask. ${ }^{64}$ The masks and musical instruments could refer to the Dionysian mystery. However, given the North African context and their conjoined appearance with xenia imagery, it is more likely that they represent the four seasons and the agricultural abundance of rural life. ${ }^{65}$

One of Dionysus' many roles in the ancient world had to do with the transition to the afterlife. This is the reason why, in Rome, the god appears on a large number of sarcophagi. This is also evident in the Dionysian funeral rites: when a high-ranking Roman citizen died, the entourage of his funeral included his own relatives and friends, as well as actors who wore wax masks in the form of the fathers of the family, professional lamenters, and dancers dressed as satyrs, which were accompanied by flutes and horns. ${ }^{66}$ The initiation into the Dionysian mystery cult carried a promise for the members of the Roman elite, who already enjoyed overprivilege in their earthly lives, that their souls would receive protection and a preferential treatment also in the afterlife. Therefore, a connection exists between elitist hedonism and initiation into mystery cults, since both are limited and exclusive. The Heraklitos mosaic expresses the two facets of the Roman elite's futile struggle against the inevitability of death: a desire to enjoy the present moment to the extreme, and an attempt to ensure an improved existence in afterlife. While the scraps of food represent the tangible world, which is observable, familiar and rational, the cultic references allude to the spiritual world, which is hidden, unknown and enigmatic.

Plato proposes the redemption of the fallen souls by enhancing the Dionysian values which are naturally present within them. Only in this manner could

62. TaC. Ann. 11.31.10; see also: Silvia Porres Caballero: "Maenadic Ecstasy in Greece: Fact or Fiction?", in Miguel Herrero de Jáuregui, Ana Isabel Jiménez San Cristóbal, Alberto Bernabé Pajares y Raquel Martin Hernández (eds.): Redefining Dionysos, Walter de Gruyter, Berlin, 2013, pp. 162-163.

63. Dunbabin: The Mosaics of Roman North Africa, pp. 173-185.

64. Louis Foucher: Découvertes Archeologiques à Thysdrus en 1961, Impr. du Secrétariat d'État aux Affaires culturelles et à l'Information, Tunis, 1961, p. $50 \mathrm{ff}$.

65. Foucher: “Une mosaïque de triclinium trouvée à Thysdrus", pp. 295-297.

66. Dion. Hal. Ant. Rom. 7.72. 
the soul free itself from the ailments, titanic in their origin, which sink it into the world of corruption, mortality and depravation. Hence, Dionysus becomes a redeeming god that could enable the soul to regain its divine nature in a way that is conveniently adapted to the particular interests of Plato's philosophy. ${ }^{67}$ Plato regards wisdom as the best way to achieve the soul's return to the divine world. For him, learning is the recollection of all the things which the soul beheld in this world and in the nether realms, and all the knowledge which it acquired ${ }^{68}$ In order to promote the return to divinity, Plato suggests harnessing the ecstatic force of Dionysus, but warns that not all who are possessed by the god are apt to benefit from his effects and to be purified by his rites. Only the true philosophers will arrive at the other world initiated and purified and will dwell with the gods, while the others would lie in the mire. ${ }^{69}$

According to Demascius, those who are properly initiated into the Dionysian mystery will experience a momentary divine revelation, which will purify them from the material world (which is a distorted reflection), and thus will gain protection in the netherworld. ${ }^{70}$ For Philo of Alexandria, vision (opsis) is the key: through vision, the mind revealed what it could not understand on its own, was drawn by the love of knowledge and beauty, was fascinated by magnificent sights (thean), and then came to the conclusion that all these were not automatically combined by irrational powers but by the mind of god (theou). ${ }^{71}$ The visual references which appear in the Heraklitos mosaic are in the form of objects that carry "disguised symbolism". They may induce a discourse which could touch on literature, philosophy, religion, morality and art. The various references to Dionysus, as well as the aesthetic choices of the representation, do not only indicate that the members of the household belonged to the Dionysian cult, but could also refer the viewers to these Platonic ideas.

The Heraklitos mosaic's inner frieze depicts the statues of Isis and Osiris against the annual flooding of the Nile (fig. 7, 8). During the Hellenistic period, the worship of Isis took the form of a cult which quickly spread throughout the Hellenistic world. The Isiac cult arrived in Sicily at the beginning of the third century BC, shortly after that reached the Greek cities on the coast of Campania, and then spread to Rome and to the rest of the Italian peninsula. ${ }^{72}$ The embracing of the cult was not uncontested. In the year 54 BC the Roman Senate passed a decree forbidding the worship of Isis within the boundaries

67. Francesc Casadesús Bordoy: "Dionysian Enthusiasm in Plato", in Miguel Herrero de Jáuregui, Ana Isabel Jiménez San Cristóbal, Alberto Bernabé Pajares, Raquel Martin Hernández (eds.): Redefining Dionysos, Walter de Gruyter, Berlin, 2013, p. 389.

68. PL. Men. 81c-d.

69. Pl. Phdr. 69c-d, see also: Bordoy: “Dionysian Enthusiasm in Plato", p. 392-393.

70. Damascius, Phd. 1.1-13 [62b2-6], 1.165-172 [69c3-69d5].

71. Philo, De specialibus legibus, 3.189.

72. Catherine Hammer: "Women, Ritual, and Social Standing in Roman Italy", in Elaine K. Gazda (ed.): The Villa of the Mysteries in Pompeii: Ancient Ritual, Modern Muse, Kelsey Museum of Archaeology and the University of Michigan Museum of Art, Ann Arbor, MI, 2000, p. 44. 
of the city of Rome, and ordered the destruction of the private temples of Isis and Serapis. In the year $19 \mathrm{AD}$, Tiberius executed the Isiac clergy. In spite of that, the activity of the cult continued, and after the death of Tiberius it saw a massive increase in popularity. In the first century, Iseum Campense and Serapeum were erected on the Campus Martius and were decorated in Egyptian style. $^{73}$ The complex was surrounded by obelisks, while rituals which simulated the flooding of the Nile symbolized the rebirth and resurrection of Osiris and created a connection between the Nile and the Tiber. ${ }^{74}$ The House of Octavius Quartio in Pompeii was redesigned after the 62 AD earthquake to include a system of water canals, as well as fourth style frescoes and marble statues, which are associated with the Isiac cult. ${ }^{75}$

The cult of Isis reached its peak during the second century AD. During this period, the number of Isiac temples that were erected in Italy increased dramatically. ${ }^{76}$ Isis was associated, among other things, with death, resurrection and fertility, and in the Graeco-Roman world was made cognate with Demeter/ Ceres and Aphrodite/Venus, and therefore could serve as almost anything to anyone. ${ }^{77}$ Perhaps for this reason, her cult increased in popularity so rapidly. ${ }^{78}$ In the Heraklitos mosaic, the Isiac references appear alongside the Dionysian ones. In the Roman world, a connection between Dionysus and Osiris was made. For example, a marble statue of Dionysus was discovered in the temple of Isis in Pompeii. ${ }^{79}$ Herodotus writes that Osiris in Greek means Dionysus, and that the Egyptians believe that Demeter/Isis and Dionysus/Osiris are rulers of the underworld. ${ }^{80}$ According to Pausanias, Dionysus is called Osiris in Egypt. ${ }^{81}$ Cicero names Dionysus "Osiris of the Nile". ${ }^{82}$ Much like Dionysus, Isis and Osiris are gods associated with the fertility of land and body, as well as with the world of the dead.

One of the best-known myths associated with the cult of Isis in the Roman world was Apuleius' Metamorphoses (150-80 AD) which tells the story of Lucius initiation. ${ }^{83}$ The narrative is characterized by liminality and by the blurring of boundaries. In Lucius' dream, it was a journey in which he approached the

73. Stewart: The Social History of Roman Art, p. 136.

74. Frederic E. Brenk: “Religion under Trajan: Plutarch's Resurrection of Osiris”, in Philip A. Stadter AND LuC VAN Der StockT (eds.): Sage and Emperor: Plutarch, Greek Intellectuals, and Roman Power in the Time of Trajan, Leuven University Press, Leuven, 2002, p. 82.

75. CLARKE: The Houses of Roman Italy, pp. 194-201.

76. Robert A. WILD: Water in the Cultic Worship of Isis and Sarapis, E. J. Brill, Leiden, 1981, p. 5.

77. Sharon Kelly Heyob: The Cult of Isis among Women in the Greco-Roman World, E. J. Brill, Leiden, 1975 , p.67.

78. Hammer: “Women, Ritual, and Social Standing in Roman Italy”, p. 45.

79. Swetnam-Burland: "Bacchus/Liber in Pompeii: A Religious Context for the Villa of the Mysteries Frieze", p. 67.

80. НDT. 2.42, 123, 144

81. PAus. 10.29.4.

82. CiC. Nat. D. 3.21-23.

83. Apul. Met. 11.24-30 
threshold of the world of Proserpina/Libra and returned through all of the elementa. He saw the midnight sun shining brightly, stayed with the deos inferos as well as with the deos superos, and worshipped them from proximity (adoravi de proximo). ${ }^{84}$ The Heraklitos mosaic operates in a similar manner: first the viewer encounters a reversal between floor and roof, and immediately after steps through the depiction of theatre masks and instruments associated with the Dionysian mystery. The scraps of food induce thoughts of a luxurious Hellenic-style banquet, while the objects themselves embody the tension between illusionism and symbolic references. Moving inwards, the next frieze depicts the flooding of the Nile, with the statues of Isis and Osiris emanating from the darkness. The aesthetics blur the boundaries between a naturalistic portrayal of the river and a mystic vision of it. The final destination of this journey is unknown since the central emblema is missing, but the whole journey could be read as a dream in which the mystic and the realistic collapse into each other.

The myth also appears in Plutarch's Moralia, which focuses more on the death and resurrection of Osiris ${ }^{85}$ Plutarch's approach had probably decisively shaped the understanding of the myth in the Roman world..$^{86}$ According to him, Osiris was the one who brought agriculture, law and the worship of the gods to Egypt. He is also the one who later traveled throughout the world and cultivated it. Osiris did not need a weapon, but defeated all nations through the magic of his persuasive talk, which was combined with songs and music of various kinds. For this reason the Greeks identify Osiris with Dionysus, and the Egyptians call him Neos Dionysos. ${ }^{87}$

The Heraklitos mosaic depicts a statue of Isis wearing a bullhorn crown on one corner, and a statue of Osiris wearing a disc on his head on the other corner. The bullhorn crown might owe itself to Plutarch's narrative, in which Typhoon is brought handcuffed to Isis, but instead of condemning him to death, the goddess releases him. In a fit of rage, Horus removes the royal diadem from Isis' head, but Hermes replaces it with a helmet decorated with bullhorns. ${ }^{88}$ The disc that appears on top of Osiris' head may represent the eclipse of the sun. According to Plutarch, Osiris is identified with the lunar world, while Typhoon is identified with the solar. The eclipse bears an allegorical meaning: a lunar eclipse occurs when the moon falls under the shadow of the earth, as Osiris fell into his coffin. The Moon also obscures the Sun, causing a solar eclipse, but does not completely annihilate the Sun, and likewise Isis did not annihilate Typhon. ${ }^{89}$ The statues of Isis that bear horns are imitations of the

84. Apul. Met., 11.23.

85. Plut. Mor. De Is. et Os. 351c-384c.

86. BRENK: “Religion under Trajan: Plutarch's Resurrection of Osiris”, p. 73.

87. Plut. Mor. De Is. et Os. 356b; see also: Ibid., pp. 75-76.

88. Plut. Mor. De Is. et Os. 356d.

89. Ibid., 367d-368e. 
crescent Moon, while the concealments and the obscuration are shown in her dark garments, as she yearningly pursues the Sun. ${ }^{90}$ Osiris' disc could also be a representation of the horizon: Nephthys is that which is beneath the earth and invisible, while Isis is that which is above the earth and visible; the circle that touches both is called the horizon, and received the name Anubis. ${ }^{91}$ Osiris' name is composed of two parts: hosion (holy) and hieron (sacred), for he is the combined relation of the things in the heavens (sacred) and the things in the lower world (holy); the relation between them is sometimes named Anubis. ${ }^{92}$

Plutarch adds that the Egyptians think of the Nile waters as the extraction of Osiris, and believe that the body of Isis is the part of land that Osiris unites with and fertilizes. ${ }^{93}$ These myths led to the formation of a Graeco-Roman mystery cult. ${ }^{94}$ Throughout the Hellenistic and Roman period, the island of Philai was a well-known pilgrimage destination, visited not only by the upper classes (governors, high officials and military officers), but also by scribes, painters and mimes. ${ }^{95}$ There, rituals that relate to the death and resurrection of Osiris took place, and were symbolically linked to the tides and flooding of the Nile. ${ }^{96}$ In Italy, rituals that were designed to simulate the flooding of the Nile took place at the temples of Isis and Serapis in Campus Martius, Rome, and at the House of Octavius Quarto in Pompeii. ${ }^{97}$ In the Roman world, a connection was made between the Nile's water and Dionysus: according to Plutarch, water is the source of all things, and Dionysus, which is none other than Osiris, is the god of nature and humidity ${ }^{98}$

The Heraklitos mosaic's representation of the flooding of the Nile includes the depiction of the river's flora and fauna. Scenes of a Nilotic nature, which portrayed exotic Egyptian animals, had grown in popularity since the beginning of the Hellenistic period. ${ }^{99}$ Typical Nilotic scenes included hippopotamuses, ducks, small Egyptian geese (Chenalopex aegyptiacus), ${ }^{100}$ and other animals bathing in the river's water, while reeds symbolized the fertility of the Egyptian soil. ${ }^{101}$ In the Heraklitos mosaic, the depiction of the Nile is not only

90. Plut. Mor. De Is. et Os. 372d-e.

91. Ibid., $368 \mathrm{f}$.

92. Ibid., 375e.

93. Ibid., 366b.

94. Ibid., 351f-352a.

95. IAN Rutherford: "Island of the Extremity. Space, Language and Power in the Pilgrimage Traditions of Philai", in David Frankfurter: Pilgrimage and Holy-Space in Late Antique Egypt, Brill, Leiden, 1998, pp. 236-240.

96. BRENK: "Religion under Trajan", p. 76

97. CLARKE: The Houses of Roman Italy, p. 194.

98. Plut. Mor. De Is. et Os. 364d-e.

99. Jerome Jordan Pollitt: Art in the Hellenistic Age, Cambridge University Press, London and New York, 1986, p. 148.

100. HDT. 2.72.

101. David Castriota: The Ara Pacis Augustae and the Imagery of Abundance in Later Greek and Early Roman Imperial Art, Princeton University Press, Princeton, NJ, 1995, p. 51. 
a naturalistic representation of the river's vegetation and wildlife, but also an allegorical representation of the Isiac cult.

A fresco from the Isiac temple in Herculaneum depicts the worship of the goddess. ${ }^{102}$ The fresco is nicknamed the "holy water procession" since in the upper plane the high priest is holding in covered hands a vessel that contains water from the Nile, considered sacred because of their association with Osiris. ${ }^{103}$ Two African ibises roam freely around the altar, while a third ibis rests on top of a sphinx and a fourth on a building to the right. A second fresco depicts the ritualistic dance of a Nubian man inside a temple. ${ }^{104}$ Here too, ibises are depicted roaming freely next to a smoking altar. These ibises were not meant as sacrifice, but carry a symbolic meaning. In the Heraklitos mosaic, an ibis is depicted sitting on a curved stone slab (fig. 8). The African ibis is sacred to Thoth, who played a role in the myth of Isis and Osiris. ${ }^{105}$ After Isis finished collecting the parts of her husband's body, it was Thoth who provided her with a magic spell that set Osiris alive. ${ }^{106}$

Geese were considered sacred to Isis and Osiris in Roman Egypt. For example, a fresco from Pompeii depicts Osiris with a bullhead, holding a Systrum, with a goose on his left. This goose's appearance is symbolic. ${ }^{107}$ The three geese depicted in the Heraklitos mosaic (fig. 7) could be viewed in a similar fashion. Two of them could be identified as Egyptian geese, typical of the Nile, according to the brown patch surrounding their eyes and the white stain beneath their wings. In nature there is a fair amount of variation in plumage tone. It is possible that Heraklitos never saw an Egyptian goose himself, and therefore borrowed several characteristics from the brown duck (Anas chlorotis). Similar ambiguity appears in other Egyptian geese depictions discovered in Italy. ${ }^{108}$ The third goose is a white domesticated one. The domestication of geese is already mentioned in the Odyssey. ${ }^{109}$ According to Livy, domesticated geese were sacred to Juno since ancient times, and therefore were raised on the Capitoline Hill. ${ }^{110}$

The Nilotic scene in the Heraklitos mosaic depicts two crocodiles. For the Romans, crocodiles and hippopotamus represented the Nile exclusively, since they did not inhabit any other rivers that were known to them. ${ }^{111}$ One of the

102. ClaRKE: The Houses of Roman Italy, p. 197.

103. BRENK: "Religion under Trajan", pp. 82-83.

104. Ibid., p. 83.

105. Antero Tammisto: Birds in Mosaics: A Study on the Representation of Birds in Hellenistic and Romano-Campanian Tessellated Mosaics, Institutum Romanum Finlandiae, Rome, 1997, pp. 54-56.

106. Geraldine Pinch: Egyptian Mythology: A Guide to the Gods, Goddesses, and Traditions of Ancient Egypt, Oxford University Press, New York, NY, 2004, pp. 80-81, 178-179; TAмmisto: Birds in Mosaics, p. 55 , n. 490.

107. Jocelyn M.C. ToynbeE: Animals in Roman Life and Art, Thames and Hudson, London, 1973, p. 263.

108. Tамміsтo: Birds in Mosaics, pp. 64-66.

109. Ном. Od. 19.535-555.

110. Livius, Ab Urbe Condita Libri, 5.47.3.

111. Tамmisto: Birds in Mosaics, p. 45. 
most popular tourist destinations in Roman Egypt was the city of Arsinoe, also known as Crocodilopolis, in which the crocodile god Sobek was worshipped. ${ }^{112}$ In the Egyptian version of myth, it was Sobek who helped Isis to heal Osiris' mutilated limbs. ${ }^{113}$ According to Plutarch, Typhon changed his shape to a crocodile in order to escape Horus. ${ }^{114}$

The Nilotic scene also includes the depiction of a small frog in between Osiris and the white goose (fig. 7). In ancient Egypt, frogs symbolized life and fertility, perhaps because millions of frogs were born in the wake of the annual flooding of the Nile. The symbol of the fertility goddess Heqet was a frog. She was associated with the flooding of the Nile and with birth. In the myth of Isis and Osiris, she is the one who breathes life into the new body of Horus. In the first centuries $\mathrm{AD}$, the artistic depiction of frogs was related to resurrection. ${ }^{115}$ Further along the same panel a big fish is depicted, only the bottom half of which is submerged in the water. Fish depictions in Roman mosaics do not tend to be naturalistic, which makes their identification difficult. ${ }^{116}$ The only part of Osiris' corpse that Isis could not retrieve was his penis, since it was immediately thrown into the river and ate by fish. Plutarch mentions three types of fish that were involved in the act: lepidotós ( $\lambda \varepsilon \pi เ \delta \omega$ tó $)$ ), a scaly fish which during the Ptolemaic dynasty often appeared in the form of a small statue; fágron ( $\phi \alpha ́ \gamma p o v)$, which probably refers to the gilt-head bream (Sparus aurata); and oxýrynchon (ó६úpuyXov), a sturgeon, which is often depicted in Egypt with an Isiac crown on its head. The fish depicted in the mosaic is golden, and therefore fits the description of a gilt-head bream, a predator with strong teeth.

In Roman art, marine animals are often depicted scattered below and over the horizon (for example a mosaic from the House of the Faun in Pompeii). Such is the case in the Heraklitos mosaic, yet no distortion is evident in the part of the fish which is submerged underwater. This stands in contrast to the Pompeiian depiction of xenia, in which objects are sometimes portrayed in distortion through transparent water glasses and jugs. This was a possible result of the increased interest in optics and the discovery of clear glass. ${ }^{117}$ Moreover, the animals are not depicted proportionally: the crocodile is smaller than the Egyptian goose opposite to it, and the latter is significantly smaller than the other Egyptian goose that swims nearby. The white goose is much smaller than the Egyptian geese (although in reality it is larger). The frog and the fish are

112. TOYNBEE: Animals in Roman Life and Art, p. 218

113. Edda Bresciani: "Sobek, Lord of the Land of the Lake", in Salima IKram (ed.): Divine Creatures: Animal Mummies in Ancient Egypt, The American University in Cairo Press, Cairo, 2005, p. 200.

114. Plut. Mor. De Is. et Os. 371e.

115. Louise A. Shier: "The Frog on Lamps from Karanis", in SAmi A. Hanna (ed.): Medieval and Middle Eastern Studies, Brill, Leiden, 1972, pp. 352-357.

116. ToynbeE: Animals in Roman Life and Art, p. 214.

117. SEN. QNat. 1.2.3, I.3.7; see also: Norman Bryson: Looking at the Overlooked: Four Essays on Still Life Painting, Reaktion, London, 1990, p. 56. 
too large in comparison to the other animals. The animals on the front plane are smaller than those which appear closer to the horizon (for example the two geese). All of which impairs the sense of realism. Based on the surviving parts, it seems that the artist chose to only include the animals that are connected with the myth of Isis and Osiris. Therefore, it is evident that the image was composed with an erudite viewer in mind, or at the very least, was meant as a reference to the Isiac cult.

The Nilotic scene includes an elongated and pointy structure that stands in the river's water (fig. 8). It is marked with signs or inscriptions which are intangible, and are probably pseudo-hieroglyphs. The context suggests this is a nilometer, which was used for measuring the Nile's water level during the annual flood season, and therefore could serve as yet another visual reference to the resurrection of Osiris. However, the structure does not resemble the nilometers which were discovered in Egypt, ${ }^{118}$ or in Pompeii. ${ }^{119}$ Nor does it match Strabo's description of a nilometer in the shape of a deep well, ${ }^{120}$ which also appears in the Nile mosaic of Palestrina. ${ }^{121}$ The closest resemblance is found in the mosaic floors of the Church of the Multiplication in Tabgha and the Nile Festival Building in Zippori, which depict a conical nilometer. ${ }^{122}$ Still, it seems that Heraklitos was probably influenced by the shape of obelisks, which were brought from Egypt to Rome, and erected, among other places, around the double temple of Isis and Serapis on the Campus Martius. ${ }^{123}$

The Nilotic scene in the Heraklitos mosaic also depicts the flora of the river. Only the tips of reeds are portrayed in order to indicate that this is the annual flood season. Prominently represented is the pink lotus (Nelumbo nucifera). Originating in Southeast Asia, it was probably brought to Egypt by the Persian Achaemenid dynasty in the sixth century BC. ${ }^{124}$ For the Romans, it was a source of wonder and amusement, which symbolized the connection to Egypt. In the first century BC it was already widespread and favoured over the blue and white lotuses, for its life cycle more closely embodied death and rebirth, ${ }^{125}$

118. Paul G. P. Меүвоом: The Nile Mosaic of Palestrina: Early Evidence of Egyptian Religion in Italy, Brill, Leiden, 1995, fig. 33, p. $61 \mathrm{ff}$.

119. Eric M. Moormann: "The Temple of Isis at Pompei", in Laurent Bricault Miguel John VerSluys And Paul G. P. Meyboom (eds.): Nile into Tiber: Egypt in the Roman World. Proceedings of the $3^{\text {rd }}$ International Conference of Isis Studies, Faculty of Archaeology, Leiden University, May 11-14, Leiden/Bosten, 2007, fig. 1 No. 4, fig. 3, pp. 143, 149.

120. Sтrabo 17.1.48.

121. Меүвоом: The Nile Mosaic of Palestrina, p. 28, fig. 15, n. 77.

122. Talila Michaeli: "Allusions to the Nile and Nilotic Landscape in Ancient Art in Israel", in Anne Gangolff (ed.), Lieux de mémoire en Orient grec à l'époque impériale, Peter Lang, Bern, 2003, p. 131.

123. Plin. hN, 36.14-15; see also: Samuel Ball Platner and Thomas Ashby: A Topographical Dictionary of Ancient Rome, Oxford University Press, London, 1929, pp. 368-369.

124. MARK Griffiths: The Lotus Quest: In Search of the Sacred Flower, Chatto and Windus, London, 2009, p. 34.

125. As the seed heads wither, they drop the seeds into the water, from which new lotus plants grow. 
and therefore, was found more suitable for ritualistic purposes. ${ }^{126}$ Pliny describes the life cycle of the pink lotus and the medicinal uses of the plant. ${ }^{127} \mathrm{Ac}-$ cording to Athenaeus, the Alexandrian poet Pancrates suggested to Hadrian to name the pink lotus after his beloved Antinous, who drowned in the Nile. ${ }^{128}$ Hence, the appearance of the pink lotus in the Heraklitos mosaic could serve as yet another visual reference to the death and resurrection of Osiris.

The rhizome of the pink lotus appears among the scraps of food depicted in the Heraklitos mosaic (fig. 5). Lotus rhizomes were boiled and served in festive banquets as early as the second century BC. ${ }^{129}$ Dioscorides mentions the pink lotus rhizome (Kuamos aiguptios) as having various beneficial effects on the stomach. ${ }^{130}$ Other parts of the pink lotus also appear in the context of a banquet. When Horace describes the celebrations that will take place at the return of an old friend, he promises to fill shining glasses with wine which induces forgetfulness. ${ }^{131}$ The word he uses for the glasses is ciboria, which is derived from kivórion (кı $ڤ \dot{\rho} \mathrm{\prime ov}$ ), the Greek word for the lotus' seed heads. ${ }^{132}$ Strabo uses the same term when he describes the glasses made from the lotus leaves to the inhabitants of Alexandria. ${ }^{133}$ Lotus flowers were used for the making of fragrant and cooling head wreathes, which were worn during summer banquets. ${ }^{134}$ The pink lotus appears as part of a banquet scene in the Nile mosaic of Palestrina. The banquet scene presumably takes place in Lake Mareotis, where Strabo witnessed the lotus-eaters. ${ }^{135}$ It includes several men and women who are drinking wine and playing flutes underneath a vine covered pergola. The depiction of pink lotus flowers in the Nilotic scene of the Heraklitos mosaic could embody all of the aforementioned meanings: it refers the viewer to Egypt, symbolizes the death and resurrection of Osiris (and possibly the Isiac disciples' hope to experience a resurrection themselves), and is connected with the sensual pleasures of the banquet and with the drinking of wine.

The allusions to the Isiac and to the Dionysian mystery cults correspond with the overall thematic programme of the Heraklitos mosaic. The visual references are not clearly expressed, and therefore must have been designed to be fully understood only by the erudite members of the Roman elite. The depiction of scraps of food, alongside the many references to the god of wine, encourage the high ranking viewers, who were invited to the banquet, to partake in the hedonistic activities which took place there, and to enjoy the sensual

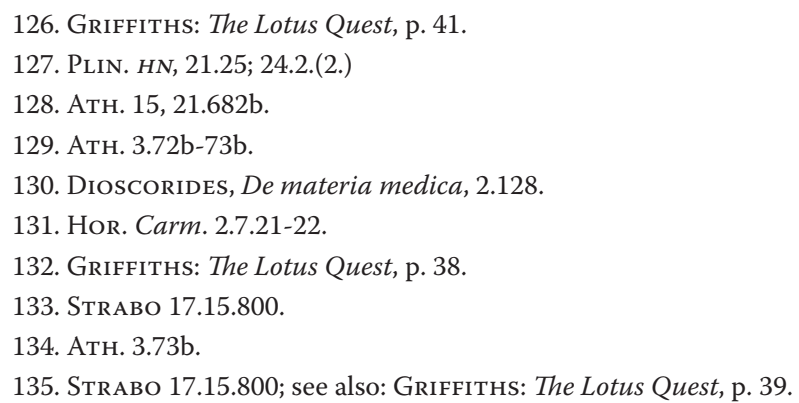


pleasures that could promote forgetfulness about being mortal. At the same time, the visual representation offers the revellers a secretive hope for a better existence in the afterlife, through allusions to the participation in the less civic and more exclusive rites of the Isiac and Dionysian mystery cults. For the highly educated viewer, the representation could also allude to Platonic ideas regarding the harnessing of the Dionysian ecstasy for the redemption of the soul.

\section{BiBLIOGRAPHY}

Anderson, Graham: The Second Sophistic: A Cultural Phenomenon in the Roman Empire, Routledge, London and New York 1993.

Blanchard-Lemée, Michele, Mongi Ennaïfer, Hedi Slim and Latifa Slim: Mosaics of Roman Africa: Floor Mosaics from Tunisia, G. Braziller, New York, 1996.

Bremmer, JAN N.: Initiation into the Mysteries of the Ancient World, Walter de Gruyter, Berlin and Boston, 2014.

Brenk, Frederic E.: "Religion under Trajan: Plutarch's Resurrection of Osiris", in Philip A. Stadter And Luc VAn Der Stockt (eds.): Sage and Emperor: Plutarch, Greek Intellectuals, and Roman Power in the Time of Trajan, Leuven University Press, Leuven, 2002, pp. 73-92.

Bresciani, Edda: "Sobek, Lord of the Land of the Lake", in Salima Ikram (ed.): Divine Creatures: Animal Mummies in Ancient Egypt, The American University in Cairo Press, Cairo, 2005, pp. 199-206.

Brilliant, Richard: Visual Narratives: Storytelling in Etruscan and Roman Art, Cornell University Press, Ithaca, NY and London, 1984.

BRÜHL, AdRIEN: Liber Pater. Origine et expansion du culte dionysiaque à Rome et dans le monde romain, Bibliothèque des Écoles Françaises d'Athènes et de Rome 175, Paris, 1953.

Bryson, Norman: Looking at the Overlooked: Four Essays on Still Life Painting, Reaktion, London, 1990.

Carucci, Margherita: The Romano-African Domus: Studies in Space, Decoration and Function, Archaeopress, Oxford, 2007.

Casadesús Bordoy, Francesc: "Dionysian Enthusiasm in Plato", in Miguel Herrero de Jáuregui, Ana Isabel Jiménez San Cristóbal, Alberto Bernabé Pajares y Raquel MarTin Hernández (eds.): Redefining Dionysos, Walter de Gruyter, Berlin, 2013, pp. 386-400.

Casadio, Giovanni: Storia del culto di Dioniso in Argolide, Gruppo Editoriale Internazionale, Rome, 1994.

Castriota, David: The Ara Pacis Augustae and the Imagery of Abundance in Later Greek and Early Roman Imperial Art, Princeton University Press, Princeton, 1995.

Clarke, John R.: The Houses of Roman Italy: 100 B.C.-250 A.D.: Ritual, Space, and Decoration, University of California Press, Berkeley and Oxford, 1991.

Cumont, Franz V. M.: "La grande inscription bacchique du Metropolitan Museum II: Commentaire religieux de l'inscription”, American Journal of Archaeology, 37, 1933, pp. 232-263.

Deonna, Waldemar And Marcel Renard: Croyances et superstitions de table dans la Rome antique, Collection Latomus, 46, Revue d'études latines, Bruxelles, 1961.

Detienne, Marcel (trans. Arthur Goldhammer): Dionysos at Large, Harvard University Press, Cambridge 1989.

Donahue, John F.: The Roman Community at the Table During the Principate, University of Michigan Press, Ann Arbor, 2004.

Donderer, Michael: "Die antiken Pavimenttypen und ihre Benennungen", Jahrbuch des deutschen archäologischen Instituts, 102, 1987, pp. 365-377. 
Dunbabin, Katherine M. D.: The Mosaics of Roman North Africa: Studies in Iconography and Patronage, The Clarendon Press, Oxford, 1978.

-: 'Sic erimus cuncti...' The Skeleton in Greco-Roman Art", Jahrbuch des Kaiserlich Deutschen Archäologischen Instituts, 101, 1986, pp. 185-255.

Elderkin, George Wicker: "Sosus and Aristophanes", Classical Philology, 32/1, 1937, pp. 74-75.

FATHY, EHUD: "The asàrotos òikos Mosaics as an Elite Status Symbol", Potestas, 10, 2017, pp. 5-30.

Foucher, Louis: Découvertes Archeologiques à Thysdrus en 1961, Impr. du Secrétariat d'État aux Affaires culturelles et à l'Information, Tunis, 1961.

—: “Une mosaïque de triclinium trouvée à Thysdrus", Latomus, 20, 1961, pp. 291-297.

Frontisi-Ducroux, Françoise: Le dieu-masque: une figure du Dionysos d'Athenes, La Decouverte, Paris, 1991.

GAUCKLER, PAUl: "Le domaine des Laberii à Uthina", Monuments et mémoires de la Fondation Eugène Piot, 3, 1896, pp. 177-230.

-: Inventaire des Mosaïques de la Gaule et de l'Afrique, volume II: Afrique Proconsulaire (Tunisie), Académie des inscriptions \& belles-lettres, Paris, 1910.

-: "Musivum opus", in Charles Victor Daremberg, Edmond Saglio and Edmond PotTIER (eds.): Dictionnaire des antiquités grecques et romaines d'après les textes et les monuments, III/2 (1904), Librarie Hachette, Paris, pp. 2088-2129.

Gicheva-Meimari, Rossitsa: "Crossbands on the Chest: Religious Realia in Ancient and Byzantine Thrace", in Charalambos Bakirtzis, Nikos Zekos and Xenophon Moniaros (eds.): Byzantine Thrace: Evidence and Remains, Verlag Adolf M. Hakkert, Amsterdam, 2011, pp. 359-362.

Gordon, RichARD: "Authority, Salvation and Mystery in the Mysteries of the Mithras", in JAnet Huskinson, Mary Beard and Joyce Reynolds (eds.): Image and Mystery in the Roman World, Alan Sutton Publishing, Gloucester, 1988, pp. 45-88.

Griffiths, MARK: The Lotus Quest: In Search of the Sacred Flower, Chatto and Windus, London, 2009.

Grummond, Elizabeth de: "Bacchic Imagery and Cult Practice in Roman Italy", in Elaine K. Gazda (ed.): The Villa of the Mysteries in Pompeii: Ancient Ritual, Modern Muse, Kelsey Museum of Archaeology and the University of Michigan Museum of Art, Ann Arbor, 2000, pp. 75-82.

Hammer, Catherine: "Women, Ritual, and Social Standing in Roman Italy", in Elaine K. Gazda (ed.): The Villa of the Mysteries in Pompeii: Ancient Ritual, Modern Muse, Kelsey Museum of Archaeology and the University of Michigan Museum of Art, Ann Arbor, 2000, pp. 38-49.

Henrichs, Albert: "Between Country and City: Cultic Dimensions of Dionysus in Athens and Attica”, in Mark Griffith and Donald J. Mastronarde (eds.): Cabinet of the Muses. Essays on Classical and Comparative Literature in Honor of Thomas G. Rosenmeyer, Scholars Press, Atlanta, 1990, pp. 257-277.

-: "Dionysos: One Or Many?", in Miguel Herrero de Jáuregui, Ana Isabel Jiménez San Cristóbal, Alberto Bernabé Pajares, Raquel Martin Hernández (eds.): Redefining Dionysos, Walter de Gruyter, Berlin, 2013, pp. 554-582.

Hernández de la Fuente, David: "Parallels between Dionysos and Christ in Late Antiquity: Miraculous Healings in Nonnus' Dionysiaca”, in Miguel Herrero de Jáuregui, Ana Isabel Jiménez San Cristóbal, Alberto Bernabé Pajares y Raquel Martin HernánDEZ (eds.): Redefining Dionysos, Walter de Gruyter, Berlin, 2013, pp. 464-487.

Heyob, Sharon Kelly: The Cult of Isis among Women in the Greco-Roman World, E. J. Brill, Leiden, 1975.

Isler-Kerenyi, Cornelia: Dionysos in Archaic Greece: An Understanding Through Images, Brill, Leiden and Boston, 2006.

Jiménez San Cristóbal, Ana Isabel: “The Sophoclean Dionysos”, in Miguel Herrero de Jáuregui, Ana Isabel Jiménez San Cristóbal, Alberto Bernabé Pajares, Raquel Martin Hernández (eds.): Redefining Dionysos, Walter de Gruyter, Berlin, 2013, pp. 272-300. 
Koortbojian, Michael: Myth, Meaning, and Memory on Roman Sarcophagi, University of California Press, Berkeley, 1995.

Lehmann, Phyllis Williams: Roman Wall Painting from Boscoreale in the Metropolitan Museum of Art, Archaeological Institute of America, Cambridge, 1953.

Massa, Francesco: Tra la vigna e la croce: Dioniso nei discorsi letterari e figurativi cristiani (II-IV secolo). Potsdamer Altertumswissenschaftliche Beiträge 47, Franz Steiner Verlag, Stuttgart, 2014.

Mazois, François: Le Palais de Scaurus, ou Description d'une maison romaine, fragment d'un voyage fait à Rome, vers la fin de la République, par Mérovir, prince des Suèves, Firmin Didot, Paris, 1819 (1859).

Meineke, August: Fragmenta Comicorum Graecorum, typis et impensis G. Reimeri, 1839.

Mеyвоom, Paul G.P.: The Nile Mosaic of Palestrina: Early Evidence of Egyptian Religion in Italy, Brill, Leiden, 1995.

Michaeli, Talila: "Allusions to the Nile and Nilotic Landscape in Ancient Art in Israel", in Anne Gangolff (ed.), Lieux de mémoire en Orient grec à l'époque impériale, Peter Lang, Bern, 2003, pp. 109-138.

Moormann, Eric M.: “The temple of Isis at Pompei”, in Laurent Bricault, Miguel John Versluys and Paul G. P. Meyboom (eds.): Nile into Tiber: Egypt in the Roman world. Proceedings of the $3^{\text {rd }}$ International Conference of Isis Studies, Faculty of Archaeology, Leiden University, May 11-14, Leiden and Boston, 2007, pp. 137-154.

Panofsky, ERwin: Early Netherlandish Paintings, Its Origins and Character, Harper \& Rowe, New York, 1971.

PARlasca, Karl: "Das pergamenische Taubenmosaïk und der sogenannte Nestor-Becher", Jahrbuch des Deutschen Archäologischen Instituts, 78, 1963, pp. 256-293.

Perpignani, Paola and Cesare Fiori: Il mosaico 'non spazzato'. Studio e restauro dell'asaroton di Aquileia, Edizioni del Girasole, Ravenna, 2012.

Pinch, Geraldine: Egyptian Mythology: A Guide to the Gods, Goddesses, and Traditions of Ancient Egypt, Oxford University Press, New York, 2004.

Platner, Samuel Ball and Thomas Ashby: A Topographical Dictionary of Ancient Rome, Oxford University Press, London, 1929.

Pollitt, Jerome Jordan: Art in the Hellenistic Age, Cambridge University Press, London and New York, 1986.

Porres Caballero, Silvia: “Maenadic Ecstasy in Greece: Fact or Fiction?", in Miguel Herrero de Jáuregui, Ana Isabel Jiménez San Cristóbal, Alberto Bernabé Pajares y Raquel Martin Hernández (eds.): Redefining Dionysos, Walter de Gruyter, Berlin, 2013, pp. 159-184.

ReINHOld, Meyer: History of Purple as a Status Symbol in Antiquity, Latomus, Bruxelles, 1970.

Renard, Marcel: "Pline l'Ancien et le motif de l'asàrotos òikos", Hommages à Max Niedermann, Collection Latomus, 23, Revue d'études latines, Bruxelles, 1956, pp. 307-314.

Ribi, Emil A.: "Asàrotos òikos - von der Kunst, die sich verbirgt", in Sabrina Buzzi, Daniel KäCH, ERICH KISTler ET AL. (eds.): Zona Archeologica: Festschrift für Hans Peter Isler zum 60. Geburtstag, R. Habelt, Bonn, 2001, pp. 361-369, pls. 55-56.

Rutherford, IAn: "Island of the Extremity. Space, Language and Power in the Pilgrimage Traditions of Philai", in David Frankfurter: Pilgrimage and Holy-Space in Late Antique Egypt, Brill, Leiden, 1998, pp. 229-256.

Salomonson, Jan Willem: Romeinse Mozaïeken uit Tunesië, Rijksmuseum van Oudheden, Leiden, 1964.

SCHEID, John: "Le thiase du Metropolitan Museum", in L'association dionysiaque dans les sociétés anciennes, Actes de la table ronde organisée par l'École Française de Rome (Rome 24-25 mai 1984), Rome, 1986, pp. 275-290.

Seaford, Richard A.S.: "Sophokles and the Mysteries", Hermes, 122, 1994, pp. 275-288.

Shier, Louise A.: "The Frog on Lamps from Karanis", in Sami A. Hanna (ed.): Medieval and Middle Eastern Studies, Brill, Leiden, 1972, pp. 352-357. 
Stewart, Peter: The Social History of Roman Art, Cambridge University Press, Cambridge, MA and New York, 2008.

Swetnam-Burland, Molly: "Bacchus/Liber in Pompeii: A Religious Context for the Villa of the Mysteries Frieze", in Elaine K. Gazda (ed.): The Villa of the Mysteries in Pompeii: Ancient Ritual, Modern Muse, Kelsey Museum of Archaeology and the University of Michigan Museum of Art, Ann Arbor, 2000, pp. 59-74.

TAmmisto, Antero: Birds in Mosaics: A Study on the Representation of Birds in Hellenistic and Romano-Campanian Tessellated Mosaics, Institutum Romanum Finlandiae, Rome, 1997.

TANner, Jeremy: The Invention of Art History in Ancient Greece: Religion, Society and Artistic Rationalisation, Cambridge University Press, Cambridge, 2006.

Toynbee, Jocelyn M. C.: Animals in Roman Life and Art, Thames and Hudson, London, 1973.

TURCAN, ROBERT: Les sarcophages romains à représentations dionysiaques, Essai de chronologie et d'histoire religieuse, Bibliothèque des Écoles Françaises d'Athènes et de Rome 210, Paris, 1966.

Werner, Klaus E.: Die Sammlungen antiker Mosaiken in den Vatikanischen Museen, Monumenti, Musei e Gallerie Pontificie, Vatican City, 1998.

Wild, Robert A.: Water in the Cultic Worship of Isis and Sarapis, E. J. Brill, Leiden, 1981.

Zanker, Paul: Roman Art, J. Paul Getty Museum, Los Angeles, 2010. 